Journal of

Entrepreneurship and

Project Management

(JEPM)

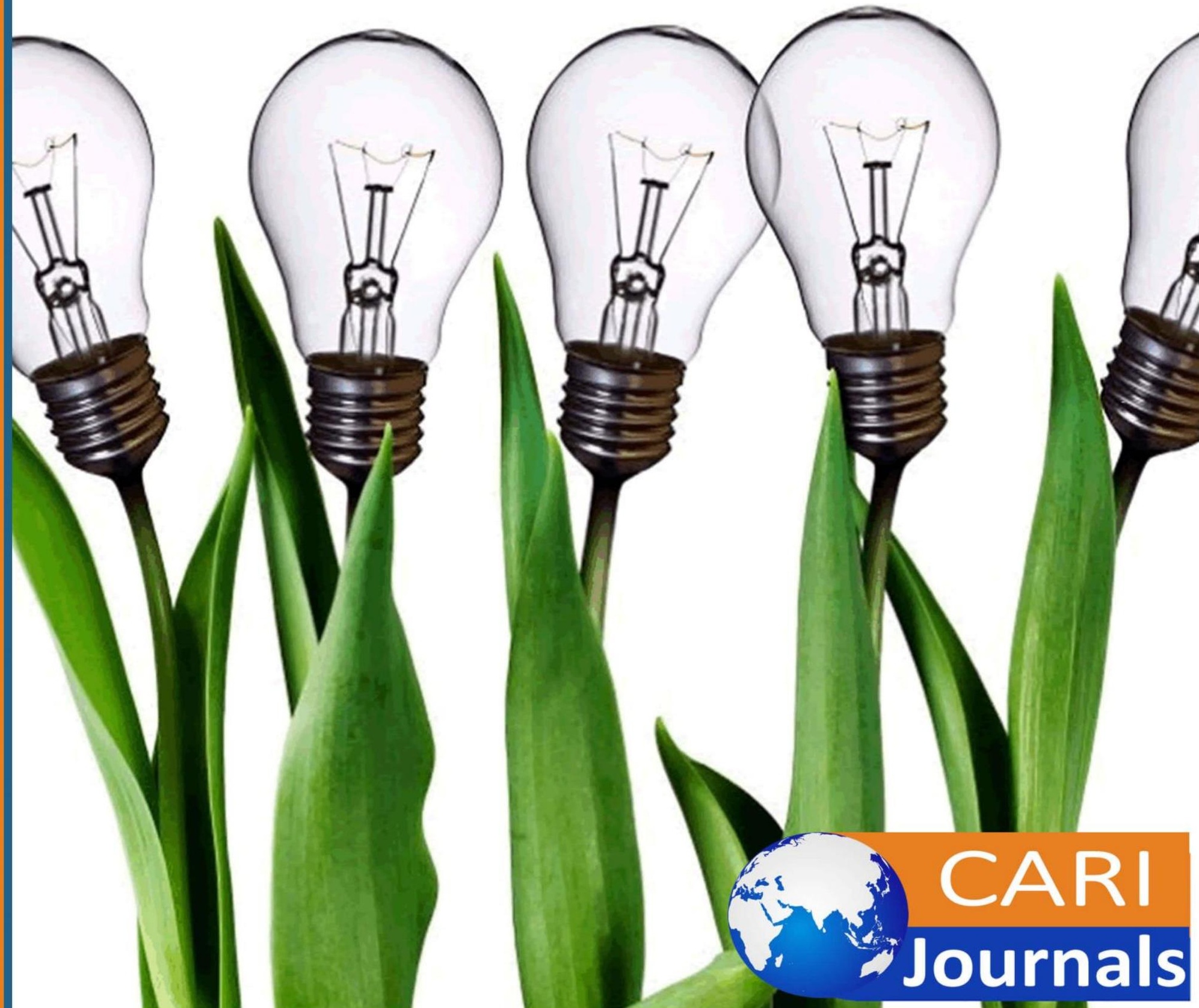


Journal of Entrepreneurship and Project Management

ISSN 2520-9116 (Online)

Vol. 6, Issue No.1, pp 24 - 48, 2021

$\underline{\text { www.carijournals.org }}$

\title{
Influence of Project Management Practices on The Implementation of Environmental Non-Governmental Organizations' Projects: A Case of World-Wide Fund for Nature- Kenya, Kwale County
}

\author{
$1^{*}$ Onsongo Binitah Bosibori \\ Postgraduate Student: University of Nairobi \\ *Corresponding Author's Email: binitahbosibori@gmail.com \\ ${ }^{2 *}$ Dr. Moses Otieno \\ Lecturer, School of Open and Distance Learning, \\ University of Nairobi \\ *Corresponding Author's Email: moses.otieno@uonbi.ac.ke
}

\begin{abstract}
Purpose: Non-Governmental Organizations are faced with project implementation challenges specifically $70 \%$ of environmental projects fail to meet their estimated timeline, budget and objectives. These factors have led researchers to look for possible solutions to pilot smooth execution of projects. The study's' drive was to institute the effect of Project Management Practices on Implementation of environmental Non-Governmental Organizations' projects: A Case of World-Wide Fund for Nature- Kenya-Kenya, Kwale County. The study measured Stakeholders' Engagement, Project Design, Project Team competence and Monitoring and Evaluation to establish their influence the execution of environmental projects of NonGovernmental Organizations.
\end{abstract}

Methodology: Descriptive research design was adopted for the study. The target population was 3,486 drawn and a sample of 90 respondents was arrived using purposive sampling. Data collection was carried out using questionnaires and analyzed using Statistical Package to develop descriptive statistics and draw inferences.

Results: The findings clearly showed that all the factors were present in environmental NGOs projects since they had high average means of 4.45, 4.22, 4.37 and 4.5 for the independent variable while the dependent variable $\mathrm{Y}$ had a mean of 4.35. Hypothesis was tested after each alternative as per the objective of the researcher using the Chi-Square test and it was determined that all the factors have significant influence on successful implementation of environmental donor-funded projects since they had a significance $P$ value of less than 0.05 . The findings further showed that all the four factors; Stakeholders' Engagement, Project Design, Project Team competence and Monitoring and Evaluation have a positive influence on implementation of environmental NonGovernmental Organizations' projects. The study established that Stakeholders' Engagement, had the highest influence on successful implementation of environmental Non-Governmental Organizations' projects with a significant positive change of $77 \%$ if a unit of it is increased, followed by Project Team competence with $72 \%$, Monitoring and Evaluation had an influence of 
Journal of Entrepreneurship and Project Management

ISSN 2520-9116 (Online)

Vol. 6, Issue No.1, pp 24 - 48, 2021

www.carijournals.org

$63 \%$ and lastly Project Planning process, had a $47 \%$ influence on sustainable implementation of environmental Non-Governmental Organizations' projects

Unique contribution to theory, policy and practice: The study recommended improved stakeholder involvement and project team competence and improving the monitoring and evaluation function for better performance of environmental Non-Governmental Organizations' projects.

Keywords: Environmental Non-Governmental Organizations' projects implementation, Stakeholders' Engagement, Project Design, Project Team competence, Monitoring and Evaluation.

\subsection{INTRODUCTION}

\subsection{Background of the Study}

Management of projects is one of oldest and most appreciated endeavors of manhood with contributions from constructors, designers and masons according to Ogunde, .et al (2017). This is demonstrated by the successful building of the pyramids, prehistoric cities, monuments and other wonders of the world. This has led to development of the project management practices which are applied to ensure smooth implementation of projects. However, there is no documentation on methodologies or techniques that were used until the mid-1950s that saw the emergence modern project management practices tools. Since then, the concept of has gained much admiration and wide acceptance in all over the world. Project objectives can be accomplished in terms of size, scope and industry thus the completion is anticipated within the shortest time possible, using minimal resources and production of quality results (Mkutano \& Sang, 2018). In this regard, for a firm to achieve performance objectives it should implement effective project management practices. According to the authors, proper project control can be achieved using project management tools which include project design planning, identification of stake holders, choosing a competent team and establishing monitoring and evaluation procedures. This creates a focused approach and deliberation between stakeholders leading to successful completion of the project.

Mavuti, Kising'u and Oyoo (2019) noted that having new strategies in theory may not help in achievement of project objectives thus proper implementation is key. Various studies have shown that in developing countries, the failure rate in implementations of projects in an organization is very high. The study by Reilly (2015), on project management practices in the public sector, reveal, poor management practice contributes approximately $30 \%$ towards public sector projects failure. Due to the high failure rate in developing countries, the scenario has increased the need for organizational accountability of the projects monies. Although the concept has infiltrated in some organizations, there is need for an understanding in application of the principle of project management practices in developing countries.

In Africa, donor-funded NGOs are organizations who provide essential humanitarian help and protection in war prone areas since the 1980s. Western donors who had become frustrated by bureaucracy and ineffectiveness of government-to-government projects saw NGOs as an alternative with more chance for successful implementation of project objectives for the organization (Turner \& Muller, 2015). In East Africa poverty is still rampant despite the increase 
Journal of Entrepreneurship and Project Management

ISSN 2520-9116 (Online)

Vol. 6, Issue No.1, pp 24 - 48, 2021

www.carijournals.org

in NGOs poverty eradication funding streams (Wanyoike \& Omwaka, 2016). Gitau, (2015), found that projects in Africa either delay or cost more than anticipated which was confirmed by findings of Diallo and Thuillier, 2014. In Kwale County, there are NGOs which engage in sectors of fisheries, agriculture, human rights and environment. WWF-Kenya began its operations in Kwale County with focus on forestry, freshwater, policy, innovation marine and fisheries. The organization has a bold and inventive approach in achievement of objectives by overcoming challenges facing these fields in cooperation with its diverse partners and stakeholders. It taps into the vast power of all the concerned stakeholder to safeguard biodiversity and direct the country to sustainability.

\subsection{Statement of the problem}

NGOs' projects have become in every country and are more involved in development agenda both locally and internationally. Nevertheless, their implementation continues to be a disappointment of project as stated by (Gregg \& Ana, 2016). Almost $70 \%$ of such projects as stated by Ochieng (2018)) fail to meet the estimated timeline, quality and budget. Project failure has become monotonous with the majority working under difficulty and unforeseen complexities, limitations and inefficient resources. Consequently, project may face delays and money flow problems because of improper planning. The inefficiencies may lead to project discontinuation as a result of increased cost and unaccountability of the managers. Kerzner (2015) opines that projects may fail to achieve targets and objectives due to low morale, de-motivation, poorly managed project tea relations and commitment. These factors are considered harmful to a projects' accomplishment in NGOs as reflected by Ika, Diallo and Thuillier (2012). Project teams within NGOs are confronted with day-to-day complicated tasks associated to project implementation as per the study by (Achieng, 2016). These encounters are associated with the unnecessary capacity to perform. Additionally, NGO staffing has become an issue due to hiring on short term contracts resulting to high turnover and limited diversity in sources of funds by NGOs.

NGOs continue facing deepened adversity from most governments, hence need to steady their operation. The NGOs role is protecting the vulnerable population and there is absolute need to address social issues and environmental issues. The move has seen NGOs being able to provide avenues for development to transform communities faced with structural inequalities. The establishments are therefore overwrought with how best to take care of community issues/needs. This has required the NGOs to forge and foster stronger relationships with the local communities as well as engaging the private sectors to collaborate in driving the same agenda. Inadequate capacity building on project sustainability by the residents of Kwale County compounds the problems encountered. In Kwale County for example, WWF-Kenya has operated for over two decades in tackling environmental issues in the area endowed with rich biodiversity. However, little investigations have been done to establish the project management practices they undertake that ensure environmental sustainability. This results to the justification of the study on Project Management Practices on the Implementation of environmental donor-funded projects of NonGovernmental Organizations: A Case of World-Wide Fund for Nature- Kenya, Kwale County. 
Journal of Entrepreneurship and Project Management

ISSN 2520-9116 (Online)

Vol. 6, Issue No.1, pp 24 - 48, 2021

$\underline{\text { www.carijournals.org }}$

\subsection{The purpose of the study}

The purpose of the study was to assess the influence of project management practices on the implementation of environmental Non- Governmental Organizations' projects: a case of WorldWide Fund for Nature- Kenya, Kwale County.

\subsection{Objectives of the study}

The study was guided by these specific objectives:

i. To establish stakeholders' engagement, influence the implementation of environmental non- governmental organizations' projects in Kwale County, Kenya

ii. To determine influence of project design on the implementation of environmental nongovernmental organizations' projects in Kwale County, Kenya

iii. To examine effect of project team commitment on the implementation of environmental non- governmental organizations' projects in Kwale County, Kenya

iv. To assess how monitoring and evaluation tools influence the implementation of environmental non- governmental organizations' projects in Kwale County, Kenya

\subsection{LITERATURE REVIEW}

\subsection{Implementation of Environmental NGOs' Projects}

Project management practices are vital aspects in the project implementation, that have to be maintained for an efficient and effective completion of the project (Dissanayaka \& Kumaraswamy, 2013). According to Ohara (2015), project management is considered as the proficiency to complete with thoroughness, a project outcome that fulfills a given mission. This can be done by the organization of a devoted project team, using the most effective management methods and technical abilities through proper planning of resources as well as monitoring and evaluation processes. Ahmed, Mohamad and Ahmad (2016) observe that leadership is effective for application by the project manager as it influences project outcome while vice versa is directly associated with project failure. Top management support in project success is vital it must empower the teams and provide required resources (Haque \& Anwar, 2012). Lester (2017), acknowledges effective communication as a vital factor in success any project. Open communication in projects give information exchanges which lead better understanding of project stakeholders needs (Ruuska, 2016). Though this is dependent on the quality of communication channels, which are evaluated as the point to which suitable persons receive the info in a timely manner for action/decision.

Allocation of resources leads to review and modify the project plan, revise stages, project completion dates (Selaru, 2012). Meredith and Mantel (2010) perceive that the resource allocation will improve the start and finish of a project. Project design gives a probable start and completion date for a project, the schedule of activities which gives a basis for performance evaluation necessary for the monitoring and evaluation process (Selaru, 2012). Stakeholders are parties that maybe affected by the project start and completion, bringing in a variety of experiences, expertise and skills to the project and can assist in project success (Bourne, 2016). Stakeholders can adversely affect the project outcome and thus identification of relevant stakeholders as well as 
Journal of Entrepreneurship and Project Management

ISSN 2520-9116 (Online)

Vol. 6, Issue No.1, pp 24 - 48, 2021

www.carijournals.org

their involvement in the project cycle is key in successful implementation of the project (Maina, 2013). Involvement of the stakeholders from the onset of the project may help the project managers to avoid future problems or clashes with the stakeholders who may put off the project.

\subsubsection{Stakeholders' Engagement and the Implementation of Environmental NGOs' Projects}

Stakeholders are persons or clusters of persons that are either directly or indirectly affected by the operations of a body, it (group) can also have a stake in the program (Infragate, 2014). The stakeholders can aid in deliberation of issues/challenges that could be experience during the project planning and execution cycle (Wanjiru, 2013). This distinctive character, therefore requires projects to engage stakeholders early in project development and operation (Kwak, 2013). NGOs in a global context, should manage the stakeholders' adversities and needs to develop vulnerable people or address their needs (Higgs, 2013). In a study by Njogu (2016) it was discovered that stakeholders' contribution to project monitoring has a helpful and substantial influence on project implementation. Nyandika and Ngugi (2014) further show that, success in construction of road projects is done by proper project communication, achieved through consultations, practicability analysis and roundtables meetings, this establishes a critical mode of effective communication when implementing projects. Mavuti, Kising'u and Oyoo, (2019) as well, concludes that absence of stakeholders' participation leads to lack of project responsibility and support which can lead to the boycott/ignorance of project issues; low perceived benefits, project sustainability, and loss of resources and lastly failure of the project.

Additionally, Silvius \& Schipper, (2014); and Project Management Institute (2013), opine that although deeper participation comes with more costs, it enhances the competitive advantage of an organization. The efficiency of project implementation depends on connection/communication/engagement of crucial stakeholders which means making joint decisions for implementation (Vanessa \& Gala, 2011). Stakeholders should fully support objectives and vision of the project to ensure successful implementation and avoid failure (Ochieng, 2018). In his study, findings indicated that the stakeholders can have an implication the plan, and development and also survival of a firm's operations.

\subsubsection{Project Design and the Implementation of Environmental NGOs' Projects}

Project design is defined in the way resources, employees, technical expertise, materials and finances are organized to undertake a project within described outputs constrained by time, budgets plus quality to achieve perceived benefits. Project design is, therefore, extensively believed to be a significant backer of project accomplishment within defined parameters in terms of time and cost (James, 2014). Various reviews have been provided with regard to planning and design. They indicate that having an efficient project design leads to successful implementation of projects in an organized manner as found thse studies by Agheneza, 2013 and Khang, \& Moe, 2014.

While undertaking project implementation, it is eminent to know that project designs' role in successful project management and how each resource is interlinked during project design. Furthermore, project design leads to effective allocation and utilization of resources that would lead to maximum output. A study found that project design can resolve inherent challenges that may hinder the project moving towards achievement its preset purposes as stated by Mavuti, et al, 
Journal of Entrepreneurship and Project Management

ISSN 2520-9116 (Online)

Vol. 6, Issue No.1, pp 24 - 48, 2021

$\underline{\text { www.carijournals.org }}$

(2019). Zwikael, (2014) noted that a successful project employs limited resources and maximizes output and effectiveness.

\subsubsection{Project Team Commitment and the implementation of Environmental NGOs' Projects}

Project team commitment is an important implementation factor thus a carefully selected team will improve the chances of project accomplishment. Project team selection needs to done in an unbiased way for sake of the project success which may be hard task to accomplish (Carson, 2009). Human resources should have proper structures, job description that match their technical knowhow. The ability to conduct evaluation of performance can also impact performance of project (Vanessa \& Gala, 2011). A study by Jhuthi and Kisimbii (2015) affirms that team competence is key in project management. Through training and multi-skill development leadership of managers can be sharpened and value of the employee to the project improved (Munchers, 2015). Firms should be consistent in these kinds of training because employees acquire the requisite skills to work and lead, according to Obisi (2011). Training also means development and enhancement of the skills that are available in the firm (Lytras, De Pablos \& Avison, 2010). Chaudhry, Kalyar and Rehman, (2012) established that for a project to succeed proper direction and management of employees is important for success of the project. Thus, leaderships skills in an important competence trait of the manager as he/she should be able to interpret objectives of the project and divide them into actionable activities and clearly communicate the same to employees with the right ability to execute them (Jing \& Avery, 2011).

\subsubsection{Monitoring and Evaluation Tools and the Implementation of Environmental NGOs' Projects}

Stakeholders of a project should be appraised of the project objectives and thus this forms a basis for monitoring and evaluation. This tool is therefore important for project management as it ensures proper management and account of the project. The continuous review and management of project activities is referred to as Project monitoring while project evaluation is the measure of the degree to which the perceived benefits of the project was achieved while incorporating an aspect of project sustainability (Njonje, Mulwa, \& Kyalo, 2012). Evaluation helps to document benefits as well as challenges during and after the project plus providing a basis to address them in future endeavors.

Phiri (2015) further determined that M\&E should be incorporated as part of the organizations' structures. Further in a study by Waithera and Wanyoike (2015) it was recommended that managers and staff involved in a project should be trained on application of M\&E for better results. In another study by Ngatia (2016) it was established that monitoring and evaluation exercises faced numerous weakness so a need for training employees on it was noted. Thus M\&E can provide crucial information which can be used for improvement of a project performance and decision making (Ochieng \& Tubey 2013). Management of M\&E is an important sustainability of the project (Gitonga, 2013). 
Journal of Entrepreneurship and Project Management

ISSN 2520-9116 (Online)

Vol. 6, Issue No.1, pp 24 - 48, 2021

$\underline{\text { www.carijournals.org }}$

\subsection{Theoretical Framework}

The two theories underpinning this study are; Stakeholder Theory and The Theory of Constraint

\subsubsection{Stakeholder Theory (ST)}

The Stakeholder theory denoted by (ST) was developed Freeman (1984). The theory proposes that as a matter of ethical issue a business must consider that needs of different individuals and groups which maybe directly or indirectly affected by the company operations (Gibson, 2000). The ST usually evaluates how the firm will relate with both the micro and macro environment and how its activities will affect both (Filippone, 2012). Use of stake holder theory in this study is crucial as established by Hill and Jones (2012) for successful implementation of a project requires the buy in of the project by the stakeholders. Walumbao (2011) established the ST provides an avenue in which community issues are identified and addressed. If this is done then project success is almost guaranteed according to Danny (2014). Stakeholder theory is used to clarify the stakeholder engagement in any setting.

\subsubsection{Theory of Constraints}

Theory of Constraints (TOC) was developed by Goldratt (1990). He aimed to help to identify constraints and more importantly how to address the same. The TOC helps managers to identify possible challenges and develop mechanisms to mitigate them or make them less harmful. This way firms are able to analyze factors that may limit achievement of project objectives and apply possible solutions. A study by Blackstone (2010), indicates that TOC has been used in many areas and that have the focus to project best practices norms. In the case of NGOs' projects implementation, the process of project planning and efforts to deliver tasks are marred with challenges. The tasks and activities are set to be completed within set expected timelines; the projects would be delivered onset date or before that date.

\subsection{Conceptual Framework}

The literature review provided a basis for presentation of the influence of project management practices against implementation of environmental NGOs' projects in figure 2.1. The dependent variable of this study is the Implementation of Non- Governmental Organizations' Donor Funded Projects whereas the independent variable is: Project Management Practices (Stakeholder's engagement, Project design, Project team competence and Monitoring and Evaluation). The moderation variables were government policies and the county government by-laws. 


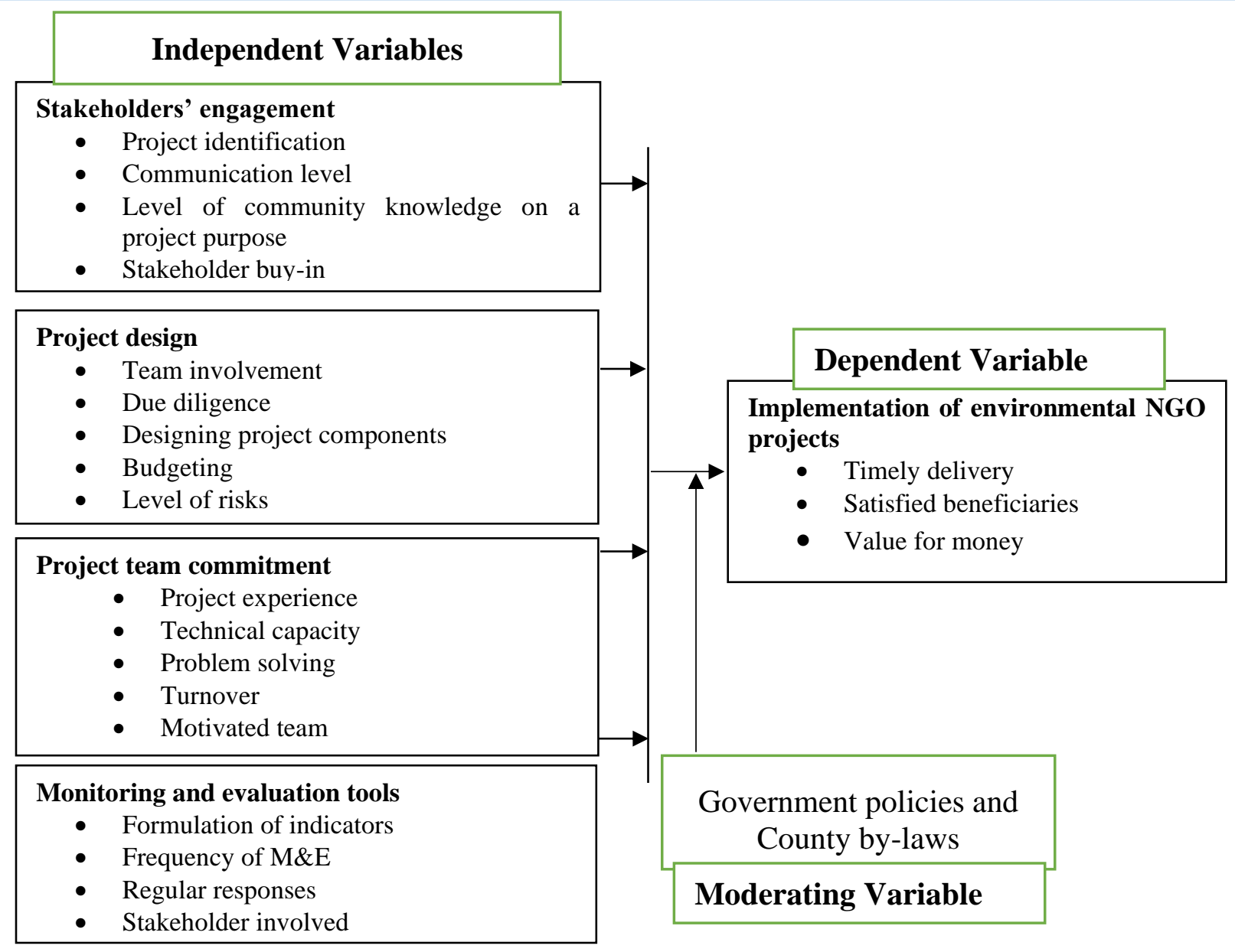

Figure 1: Conceptual Framework

Source: (Author, 2020) 


\subsection{Knowledge Gap}

This level the study discussed research knowledge gap as illustrated in table 1 .

\section{Table 1: Knowledge Gaps}

\begin{tabular}{|c|c|c|c|c|}
\hline Objective & Author & Findings & Knowledge Gap & $\begin{array}{l}\text { How Gap was } \\
\text { Addressed }\end{array}$ \\
\hline $\begin{array}{l}\text { 1. To examine how } \\
\text { stakeholders' } \\
\text { engagement } \\
\text { influences the } \\
\text { implementation of } \\
\text { environmental } \\
\text { NGOs' projects in } \\
\text { Kwale County. }\end{array}$ & $\begin{array}{l}\text { Njogu } \\
(2016)\end{array}$ & $\begin{array}{l}\text { The study discovered } \\
\text { stakeholder that } \\
\text { contribution in project } \\
\text { monitoring and } \\
\text { evaluation has an } \\
\text { influence on project } \\
\text { implementation }\end{array}$ & $\begin{array}{l}\text { There was a } \\
\text { knowledge gap on } \\
\text { what level the } \\
\text { stakeholders were } \\
\text { involved in the } \\
\text { project } \\
\text { monitoring and } \\
\text { evaluation. }\end{array}$ & $\begin{array}{l}\text { This research } \\
\text { focused on all- } \\
\text { inclusiveness of all } \\
\text { project actors } \\
\text { including donors } \\
\text { and community } \\
\text { implementation. }\end{array}$ \\
\hline $\begin{array}{l}\text { 2. To determine how } \\
\text { project design } \\
\text { influences the } \\
\text { implementation of } \\
\text { environmental } \\
\text { NGOs' projects in } \\
\text { Kwale County. }\end{array}$ & $\begin{array}{l}\text { Novo, } \\
\text { Landis } \\
\text { and } \\
\text { Haley } \\
\text { (2017) }\end{array}$ & $\begin{array}{l}\text { The study results } \\
\text { revealed that the } \\
\text { planning activity is } \\
\text { directly related to the } \\
\text { manager proficiency. } \\
\text { Equally, the manager's } \\
\text { leadership helps in } \\
\text { efficacious conclusion } \\
\text { of the project. }\end{array}$ & $\begin{array}{l}\text { Typically, the } \\
\text { process of } \\
\text { planning is not a } \\
\text { one-person task. } \\
\text { The study was } \\
\text { biased singling } \\
\text { out project } \\
\text { manager. }\end{array}$ & $\begin{array}{l}\text { This study will be } \\
\text { on inclusivity and } \\
\text { collective } \\
\text { responsibility to } \\
\text { the project team in } \\
\text { the design on } \\
\text { project } \\
\text { implementation }\end{array}$ \\
\hline $\begin{array}{l}\text { 3. To examine how } \\
\text { Project Team } \\
\text { Commitment } \\
\text { influences the } \\
\text { implementation of } \\
\text { environmental } \\
\text { NGOs' projects in, } \\
\text { Kwale County. }\end{array}$ & $\begin{array}{l}\text { Jhuthi B, } \\
\text { and } \\
\text { Kisimbii } \\
\text { J (2015) }\end{array}$ & $\begin{array}{l}\text { The findings were } \\
\text { indicative that } \\
\text { competence of the } \\
\text { team, stakeholder } \\
\text { engagement and having } \\
\text { management system } \\
\text { have a positive } \\
\text { influence on } \\
\text { implementation } \\
\text { performance. }\end{array}$ & $\begin{array}{l}\text { The study dealt } \\
\text { with the } \\
\text { competence of the } \\
\text { management team } \\
\text { and general } \\
\text { findings that } \\
\text { community } \\
\text { participation was } \\
\text { effective. } \\
\text { However, the } \\
\text { study was } \\
\text { conducted five } \\
\text { years down the } \\
\text { line. Hence the } \\
\text { dynamics have } \\
\text { changed. }\end{array}$ & $\begin{array}{l}\text { This study was } \\
\text { done in Kwale } \\
\text { County and where } \\
\text { the community will } \\
\text { be key decision- } \\
\text { makers as they will } \\
\text { be fully involved } \\
\text { together with other } \\
\text { key actors in the } \\
\text { implementation of } \\
\text { projects. }\end{array}$ \\
\hline $\begin{array}{l}\text { 4. To assess how } \\
\text { Monitoring and } \\
\text { Evaluation Tools } \\
\text { influences the } \\
\text { implementation of } \\
\text { environmental } \\
\text { NGOs' projects in } \\
\text { Kwale County. }\end{array}$ & $\begin{array}{l}\text { Ngatia } \\
(2016)\end{array}$ & $\begin{array}{l}\text { The study established } \\
\text { that monitoring and } \\
\text { evaluation of project } \\
\text { have numerous } \\
\text { challenges which need } \\
\text { to be addressed and } \\
\text { incorporated in the } \\
\text { organization structure. }\end{array}$ & $\begin{array}{l}\text { This study was } \\
\text { biased as it stated } \\
\text { and focused clear } \\
\text { on the } \\
\text { Weaknesses of } \\
\text { M\& E } \\
\text { government } \\
\text { projects. practices } \\
\text { influence } \\
\text { including M\&E }\end{array}$ & $\begin{array}{l}\text { This study, } \\
\text { therefore, focused } \\
\text { on NGOs' projects } \\
\text { and see how best } \\
\text { management can } \\
\text { improve the M\& E } \\
\text { earlier in planning } \\
\text { of development } \\
\text { plans. }\end{array}$ \\
\hline
\end{tabular}


Journal of Entrepreneurship and Project Management

ISSN 2520-9116 (Online)

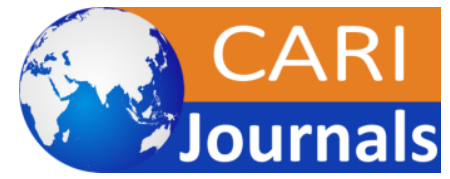

Vol. 6, Issue No.1, pp 24 - 48, 2021

$\underline{\text { www.carijournals.org }}$

\subsection{RESEARCH METHODOLOGY}

\subsection{Research Design}

The study used the descriptive survey design as helps in discovering solutions on certain problems when used in qualitative and quantitative data analysis.

\subsection{Target Population}

The study focused on a target population for households in Dzombo ward, Lunga lunga constituency which was 872 (WWF, 2020).

\subsection{Sample Size}

The sample was selected using the Yamane Formula of (1967). Hence

$$
n=\frac{N}{1+N(e)^{2}}
$$

Where; $\mathrm{n}=$ sample (required responses), e2 $=$ Margin of error $=95 \%, \mathrm{~N}=$ sample size

$$
n=\frac{872}{1+872(0.05)^{2}}
$$

Therefore, $\mathrm{n}=273.54$ : approximately 274 people

\subsubsection{Sample Technique and Procedure}

Systemic random sampling technique was used to select the research respondents to ensure that $4^{\text {th }}$ every element of the households had an equivalent chance of being chosen. The sample size was 274 thus 69 respondents from the households was selected. The other significant stakeholders (officials) were selected from the affected agencies in Kwale County totaling to 22 experts this is sample was as follows WWF officials 6 Kenya Wildlife Service (KWS) 5, Kenya Forest Service (KFS) 4 and County Government of Kwale (CGK) 7 were also considered in the sample. Making a total of 91 respondents. 
Journal of Entrepreneurship and Project Management

ISSN 2520-9116 (Online)

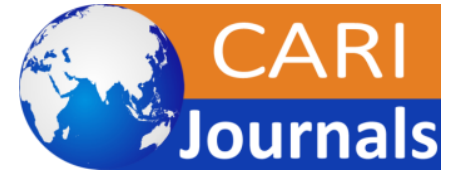

Vol. 6, Issue No.1, pp 24 - 48, 2021

www.carijournals.org

\subsection{Data Collection}

Data collection was done using primary data which was collected by use of questionnaires. The study had structured questionnaires using Likert scale questions were thus used for data collection since the responses would be easily identifiable and subjective to computation. This was pegged on Kothari (2004) asserting that survey was best suited for a descriptive study as it is easy to analyse and make conclusions

\subsection{Data Analysis}

The primary data from the field was first edited then coding done to condense data into practicable summaries. The researcher used multiple regression analysis to measure the relationship and significance between variables. The regression model was:

$$
\mathrm{Y}=\boldsymbol{\beta 0}+\beta 1 \mathrm{X}_{1}+\beta 2 \mathrm{X}_{2}+\beta 3 \mathrm{X}_{3}+\beta 4 \mathrm{X}_{4}+\varepsilon
$$

\section{Where:}

$$
\begin{aligned}
& \mathbf{Y}=\text { Implementation of projects of NGOs, } \\
& \boldsymbol{\beta 0}=\text { Constant } \\
& \boldsymbol{\beta 1} \text { - } \beta 4=\text { Beta coefficients } \\
& \mathbf{X}_{\mathbf{1}}=\text { Stakeholders Engagement } \\
& \mathbf{X}_{\mathbf{2}}=\text { Project Design } \\
& \mathbf{X}_{\mathbf{3}}=\text { Project Team Commitment } \\
& \mathbf{X}_{\mathbf{4}}=\text { Monitoring and Evaluation Tools } \\
& \boldsymbol{\varepsilon}=\text { Error Term }
\end{aligned}
$$

\subsection{DATA ANALYSIS, PRESENTATION AND INTERPRETATION}

\subsection{Questionnaire Response Rate}

The study targeted 91 respondents 82 responded to the questionnaires. This reflected a $90 \%$ response rate which according to Mugenda and Mugenda (2012), in any social survey, a response percentage of beyond $70 \%$ is considered adequate.

Table 2: Response Rate

\begin{tabular}{lll}
\hline STATUS & Frequency & Percentage $\mathbf{( \% )}$ \\
\hline Targeted & 91 & $100 \%$ \\
Responded & 82 & $90.1 \%$ \\
Discrepancy & $\mathbf{9}$ & $\mathbf{9 . 9 \%}$ \\
\hline
\end{tabular}

Table 2 confirmed $90.1 \%$ of response return rate a reflection that all respondents were sufficiently involved in the study. 
Journal of Entrepreneurship and Project Management

ISSN 2520-9116 (Online)

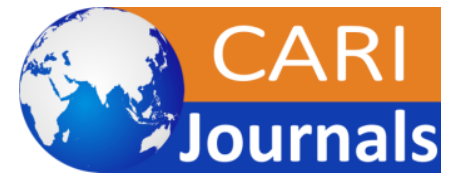

Vol. 6, Issue No.1, pp 24 - 48, 2021

www.carijournals.org

4.2 Descriptive Statistics for the Implementation of Donor Funded Environmental Projects by NGOs'

The study set examine the dependent variable to determine the presence of the variable in donor funded projects in Kwale County.

\subsubsection{Descriptive statistics for Implementation Donor funded Environmental Projects}

The researcher developed descriptive statistics out of the responses given on the dependent variable. The results were presented in table 3 .

Table 3: Descriptive Statistics for the Implementation of Environmental Projects

\begin{tabular}{lll} 
Statement & Mean & Std. Dev \\
\hline $\begin{array}{l}\text { Environmental projects are completed on time or earlier } \\
\text { The environmental improved the livelihood of target communities }\end{array}$ & 4.65 & 0.82 \\
$\begin{array}{l}\text { The projects were beneficial to the community } \\
\begin{array}{l}\text { Monitoring and evaluation keep programs on track and within budgets } \\
\text { hence efficiency and cost effectiveness enhanced. }\end{array}\end{array}$ & 3.74 & 0.673 \\
\hline Composite Mean and std dev. & $\mathbf{4 . 3 9}$ & $\mathbf{0 . 7 7 9}$ \\
\hline
\end{tabular}

The table 3 reveal that the respondents agree that there was successful implementation of environmental projects by NGO's in Kwale County, which was shown by a composite mean of 4.39 thus further analysis can be made.

\subsection{Project Management Practices and Implementation of Environmental Non- Governmental Organizations' Projects}

Descriptive statistics and analysis were used to institute the level of project management practices in the implementation of environmental NGOs' projects.' 
Journal of Entrepreneurship and Project Management

ISSN 2520-9116 (Online)

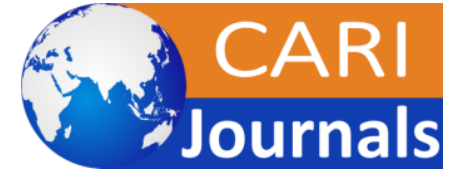

Vol. 6, Issue No.1, pp 24 - 48, 2021

www.carijournals.org

\subsubsection{Descriptive Statistics on Stakeholders' Engagement influence in implementation of Environmental NGOs' projects}

The table 4 shows the statistics in reference to the influence of stakeholders' engagement on the implementation of environmental NGOs' projects.

Table 4: Descriptive Statistics for Stakeholders' Engagement Influence

\begin{tabular}{lcc}
\hline STATEMENTS & MEAN & STD.DEVIATION \\
\hline $\begin{array}{l}\text { Project Identification influence implementation of } \\
\text { environmental NGOs' projects. }\end{array}$ & 4.44 & 0.710 \\
$\begin{array}{l}\text { Communication level influences the implementation o } \\
\text { environmental NGOs' projects. }\end{array}$ & 4.60 & 0.554 \\
$\begin{array}{l}\text { Level of Community Knowledge on Project purpose } \\
\text { influences the implementation of environmental }\end{array}$ & 4.19 & 0.762 \\
$\begin{array}{l}\text { NGOs' projects. } \\
\begin{array}{l}\text { Mapping community concerns influences } \\
\text { the implementation of environmental donor-funded } \\
\text { projects of NGOs. }\end{array}\end{array}$ & 4.47 \\
$\begin{array}{l}\text { Stakeholders' buy-in influences the implementation } \\
\text { of environmental NGOs' projects. }\end{array}$ & 4.58 & 0.714 \\
\hline Composite Mean and Standard Deviation & $\mathbf{4 . 4 5 3 2}$ & 0.708 \\
\hline
\end{tabular}

Table 4 show majority of the respondents strongly support implementation of environmental donor-funded projects of NGOs have stakeholder involvement represented by a mean of 4.45. This is confirmed by a Standard deviation of 0.421 which is less than 1 indicating that majority of respondents responses were clustered along the strongly agree response.

\subsubsection{Inferential Statistics for Stakeholders' Engagement influence in the implementation of Environmental NGOs' projects}

The researcher used chi square to determine the rejection or acceptance of the hypothesis. The first objective was hypothesized that: $\mathbf{H}_{1}$ There is a significant relationship between Stakeholders' engagement and the implementation of environmental Non- Governmental Organizations' projects.

Table 5: Chi-square test in the results Stakeholders' Engagement influence in the implementation of Environmental NGOs' projects

\begin{tabular}{lccc} 
& Value & Df & Asymp. Sig. (2-sided) \\
\hline Pearson Chi-Square & $102.472^{\mathrm{a}}$ & 9 & .000 \\
Likelihood Ratio & 85.457 & 9 & .000 \\
Linear-by-Linear Association & 32.115 & 1 & .000 \\
N of Valid Cases & 82 & & \\
\hline
\end{tabular}

a. 10 cells $(72.5 \%)$ have expected count less than 5. The minimum expected count is .02 .

From the table 5 the results of the chi-square test statistic were 102.472 and the $\mathrm{p}$ Value of the asymptotic significance was 0.000 , which is less than the alpha level of significance of 0.05 . 
Journal of Entrepreneurship and Project Management

ISSN 2520-9116 (Online)

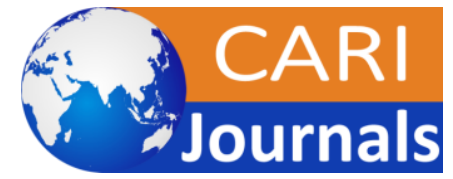

Vol. 6, Issue No.1, pp 24 - 48, 2021

www.carijournals.org

Therefore, there assumption that there is a statistically significant association between Stakeholders' Engagement and in the implementation of Environmental NGOs'. Thus, the researcher accepts the alternative hypothesis.

\subsection{Project Design influence in implementation of Environmental NGOs' Projects}

The researcher established the extent to which project design had an influence on the implementation of the projects.

\subsubsection{Descriptive Statistics on how Project Design influences the Implementation of Environmental NGOs' Projects}

Descriptive statistics in Table 6 was used to measure the influence of project design on the implementation of environmental NGOs' projects

Table 6: Descriptive Statistics for Project Design Influence

\begin{tabular}{|c|c|c|}
\hline STATEMENTS & MEAN & STD.DEVIATION \\
\hline $\begin{array}{l}\text { Funding provision influence the implementation of } \\
\text { environmental NGOs' projects. }\end{array}$ & 4.69 & 0.485 \\
\hline $\begin{array}{l}\text { Team Involvement influences the operation of } \\
\text { environmental NGOs' projects. }\end{array}$ & 4.44 & 0.596 \\
\hline $\begin{array}{l}\text { Project Scheduling influences the implementation of } \\
\text { environmental NGOs' projects. }\end{array}$ & 3.97 & 0.844 \\
\hline Organization tools concerns influences the & 4.01 & 0.737 \\
\hline $\begin{array}{l}\text { implementation of environmental NGOs' projects. } \\
\text { Level of risks influences the implementation of } \\
\text { environmental NGOs' projects. }\end{array}$ & 4.02 & 0.812 \\
\hline Composite Mean and Std Deviation & 4.2274 & 0.44589 \\
\hline
\end{tabular}

Descriptions as specified from Table 6 had a composite mean of 4.2274 and Standard deviation of 0.44589 implying the majority of the respondent agree with the prepositions made in project design.

\subsubsection{Inferential Statistics for Project Design influence in the implementation of Environmental NGOs' projects}

The researcher used chi square for testing the hypothesis and for the degree to which Project Design effect in the implementation of Environmental NGOs' projects.

H1 There is a significant relationship between Project Design and the implementation of environmental Non- Governmental Organizations' projects.

Table 7: Chi-square test Project Design influence in implementation of Environmental NGOs' projects

\begin{tabular}{llcc}
\hline & Value & Df & Asymp. Sig. (2-sided) \\
\hline Pearson Chi-Square & $123.125^{\mathrm{a}}$ & 9 & .001 \\
Likelihood Ratio & 73.33 & 9 & .002 \\
Linear-by-Linear Association & 42.762 & 1 & .001 \\
N of Valid Cases & 82 & & \\
\hline
\end{tabular}

a. 10 cells (72.6\%) have expected count less than 5. The minimum expected count is .10. 
Journal of Entrepreneurship and Project Management

ISSN 2520-9116 (Online)

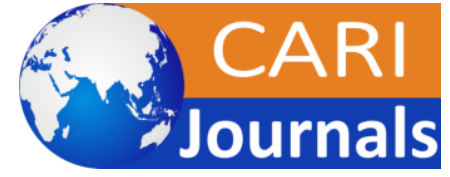

Vol. 6, Issue No.1, pp 24 - 48, 2021

www.carijournals.org

From the table 7 the probability of the chi-square test statistic is 123.125 and the $\mathrm{p}$ Value was 0.001 , which is less than the alpha level of significance of 0.05 . Therefore, indicate an association between Project Design and implementation of Environmental NGOs' projects thus the study accepts the alternative hypothesis.

\subsection{Project Team Commitment influence the Implementation of Environmental NGOs' Projects}

The study sought to establish the how Project Team Commitment influences the implementation of environmental NGOs' projects.

\subsubsection{Descriptive Statistics on Project Team Commitment Factor}

In an effort to explain how project team commitment influences the implementation of environmental NGOs' projects, descriptive statistics was developed in table 8

Table 8: Descriptive Statistics on Project Team Commitment Factor

\begin{tabular}{|c|c|c|}
\hline STATEMENTS & MEAN & STD.DEVIATION \\
\hline $\begin{array}{l}\text { Project Experience influences the implementation } \\
\text { environmental NGOs' projects. }\end{array}$ & 4.20 & 0.752 \\
\hline $\begin{array}{l}\text { Technical Capacity influences the implementation o } \\
\text { environmental NGOs' projects. }\end{array}$ & 4.34 & 0.612 \\
\hline $\begin{array}{l}\text { Problem Solving influences the implementation of } \\
\text { environmental NGOs' projects. }\end{array}$ & 4.23 & 0.643 \\
\hline $\begin{array}{l}\text { Team turn over influences the implementation o } \\
\text { environmental NGOs' projects. }\end{array}$ & 4.43 & 0.781 \\
\hline $\begin{array}{l}\text { Employee motivation influences the implementation o } \\
\text { environmental NGOs' projects. }\end{array}$ & 4.69 & 0.464 \\
\hline Composite Mean and Std Deviation & 4.3723 & 0.6504 \\
\hline
\end{tabular}

The descriptive statistics showed a mean of 4.3723and standard deviation of 0.6 indicating that the respondents agree that there is a strong element of project team commitment in the implementation of environmental NGOs projects.

\subsubsection{Inferential Statistics for Project Team Commitment influence in the implementation of Environmental NGOs' Projects}

The researcher sought to verify the impact of monitoring and evaluation on SICSP.

Objective three was hypothesized as follows: $\mathbf{H}_{\mathbf{1}}$ There is a significant relationship between Project Team Commitment and implementation of environmental Non- Governmental Organizations' projects. 
Journal of Entrepreneurship and Project Management

ISSN 2520-9116 (Online)

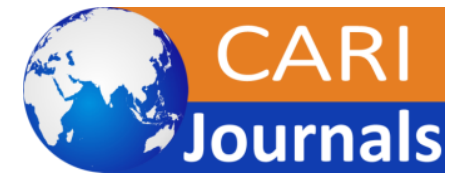

Vol. 6, Issue No.1, pp 24 - 48, 2021

www.carijournals.org

Table 9: Chi Square Test for Project Team Commitment and the implementation of Environmental NGOs' projects

\begin{tabular}{lccc}
\hline & Value & Df & Asymp. Sig. (2-sided) \\
\hline Pearson Chi-Square & $115.543^{\mathrm{a}}$ & 9 & .002 \\
Likelihood Ratio & 65.201 & 9 & .000 \\
Linear-by-Linear Association & 33.103 & 1 & .001 \\
N of Valid Cases & 82 & & \\
\hline a. 5 cells (41.7\%) have expected count less than 5. The minimum expected count is .03.
\end{tabular}

The findings on table 9 indicate the probability of the chi-square test statistic of 115.543 and the significance value was $\mathrm{p}=0.002$, this is less than the alpha level of significance of 0.05 . Thus from the findings the study accepts the alternative hypothesis that there is a strong statistical significant association between the two variables

\subsection{Monitoring and Evaluation Tools influence on Implementation of Environmental NGOs' projects}

The researcher sought to institute the effect of monitoring and evaluation tools on the implementation of environmental NGOs' projects.

\subsubsection{Descriptive Statistics on Monitoring and Evaluation Tools}

To establish the presence of monitoring and evaluation tools in the implementation of environmental NGOs' projects descriptive statistics was used. The descriptive statistics were presented in table 10

Table 10: Descriptive statistics on Monitoring and Evaluation Tools

\begin{tabular}{lcc}
\hline STATEMENTS & MEAN & STD.DEVIATION \\
\hline $\begin{array}{l}\text { Availability of resources influences the implementation of } \\
\text { environmental NGOs' projects. }\end{array}$ & 4.80 & 0.428 \\
$\begin{array}{l}\text { M\&E specialists influence the implementation of } \\
\text { environmental NGOs' projects. }\end{array}$ & 4.09 & 0.759 \\
$\begin{array}{l}\text { Formulation of indicators influences the implementation of } \\
\text { environmental NGOs' projects. }\end{array}$ & 4.45 & 0.580 \\
$\begin{array}{l}\text { Regular responses influence the implementation of } \\
\text { environmental NGOs' projects. }\end{array}$ & 4.57 & 0.647 \\
$\begin{array}{l}\text { Involvement of stakeholders influences the implementation } \\
\text { of environmental NGOs' projects. }\end{array}$ & 4.64 & 0.65501 \\
\hline \begin{tabular}{l} 
Composite Mean and Standard Deviation \\
\hline
\end{tabular} & $\mathbf{4 . 5 1 0 6}$ & $\mathbf{0 . 3 2 6 0 9}$ \\
\hline
\end{tabular}

From the descriptive statistics, the mean for monitoring and evaluation was 4.501 which indicate a strongly agree response and the standard deviation of 0.326 which means that most repondents strongly agree that monitoring and evaluation tools are present in implementation of environmental projects. 
Journal of Entrepreneurship and Project Management

ISSN 2520-9116 (Online)

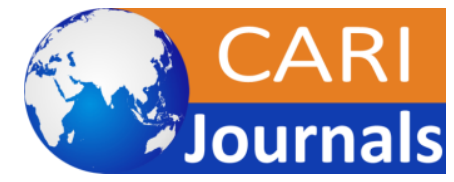

Vol. 6, Issue No.1, pp 24 - 48, 2021

www.carijournals.org

\subsubsection{Inferential Statistics for Monitoring and Evaluation Tools and Implementation of Environmental NGOs' projects}

The researcher used chi square to test the hypothesis for objective number four which was hypothesized that: $\mathbf{H}_{1}$ There is a significant relationship between Monitoring and Evaluation Tools and implementation of environmental Non- Governmental Organizations' projects.

Table 11: Chi square test in the result of relationship between inter-agency partnership and implementation of child safeguarding program

\begin{tabular}{|c|c|c|c|}
\hline & Value & df & Asymp. Sig.(2-sided \\
\hline Pearson Chi-Square & $105.008^{\mathrm{a}}$ & 9 & .000 \\
\hline Likelihood Ratio & 83.001 & 9 & .001 \\
\hline Linear-by-Linear Association & 53.378 & 1 & .000 \\
\hline $\mathrm{N}$ of Valid Cases & 82 & & \\
\hline
\end{tabular}

a. 10 cells $(62.5 \%)$ have expected count less than 5. The minimum expected count is .03.

Findings on table 11 show that there is a significant the study concludes a sturdy relationship amid monitoring and evaluation tools and implementation of environmental NGOs projects which is shown by a chi-square test statistic $=105.008$ and $P$ value was $p=0.000$ which is less than the alpha level of significance of 0.05 . Thus, the study rejects the null hypothesis and accepts the alternative hypothesis.

\subsection{Influence of Project Management Practices on the Implementation of Environmental NGOs' Projects}

The researcher pursued to further analyze the extent of the association amongst project management tools and implementation of Environmental NGOs' Projects in Kwale County. The findings were presented in tables 12, 13 and 14

Table 12: Model Summary

\begin{tabular}{llllllllllll}
\hline Model & $\mathbf{R}$ & $\mathbf{R}^{2}$ & $\begin{array}{l}\text { Adjusted } \\
\text { Square }\end{array}$ & $\begin{array}{l}\text { RStd. Error } \\
\text { of the Estimate }\end{array}$ & \multicolumn{2}{l}{$\begin{array}{l}\text { Change Statistics } \\
\text { R SquareF Change } \\
\text { Change }\end{array}$} & df1 & df2 & $\begin{array}{l}\text { Sig. } \\
\text { Change }\end{array}$ \\
\hline 1 & $.908^{\mathrm{a}}$ & .845 & .843 & .36587 & .845 & 264.462 & 1 & 56 & .000 \\
\hline
\end{tabular}

a. Predictors: (Constant), $X_{1}, X_{2}, X_{3}$ and $X_{4}$

The table 12 shows the adjusted $\mathrm{R}^{2}$ as 0.843 meaning that $84.3 \%$ of the successful implementation of Environmental NGOs' Projects can be accounted by project management tools when holding other factors constant.

Table 13 ANOVA

\begin{tabular}{llrrrrr}
\hline Model & & Sum of Squares & Df & Mean Square & F & Sig. \\
\hline 1 & Regression & 7.132 & 3 & 1.783 & 9.416 & $.000^{\mathrm{b}}$ \\
& Residual & 13.635 & 79 & .189 & & \\
& Total & 20.767 & 82 & & &
\end{tabular}

a. Dependent Variable: Implementation of Environmental NGOS' Projects

b. Predictors:(Constant), Stakeholders' Engagement, Project Design, Project Team competence and Monitoring and Evaluation 
Journal of Entrepreneurship and Project Management

ISSN 2520-9116 (Online)

Vol. 6, Issue No.1, pp 24 - 48, 2021

www.carijournals.org

From the Analysis of variance (ANOVA) table 13 findings were used to deduce if their significant differences between the study variable means, the findings show that $\mathrm{F}(3,79)=9.416$; $\mathrm{P}$ value $=$ 0.000 , the $\mathrm{F}$ value was above 2 and $\mathrm{P}$ value less than 0.05 therefore the conclusion that there is a significant relationship between the variables under study.

Table 14: Regression Coefficients

\begin{tabular}{|c|c|c|c|c|c|c|}
\hline \multirow{2}{*}{\multicolumn{2}{|c|}{ Model }} & \multicolumn{2}{|c|}{$\begin{array}{c}\text { Unstdzed } \\
\text { Coefficients }\end{array}$} & \multirow{2}{*}{$\begin{array}{c}\begin{array}{c}\text { Stdzd } \\
\text { Coefficients }\end{array} \\
\text { Beta }\end{array}$} & \multirow[t]{2}{*}{$\mathbf{T}$} & \multirow[t]{2}{*}{ Sig. } \\
\hline & & $\mathrm{B}$ & Std. Error & & & \\
\hline \multirow[t]{5}{*}{1} & (Constant) & .254 & .031 & & 1.101 & .002 \\
\hline & Stakeholders' Engagement (X1) & .567 & .082 & .202 & 1.102 & .001 \\
\hline & Project Design(X2) & .412 & .080 & 201 & 0.301 & .000 \\
\hline & Project Team Competence (X3) & .623 & .084 & .021 & 1.151 & .001 \\
\hline & Monitoring and Evaluation(X4) & .829 & .090 & .223 & 0.231 & .000 \\
\hline
\end{tabular}

a. Dependent Variable: Implementation of Environmental NGOS' Projects

Table 14 also shows the beta coefficients of constructs that constitute the four independent variables that predict the dependent variable (implementation of Environmental NGOs' Projects). The regression model equation was represented as shown in the following equation;

$$
\mathrm{Y}=0.254+0.567\left(\mathrm{X}_{1}\right)+\mathbf{0 . 4 1 2}\left(\mathrm{X}_{2}\right)+\mathbf{0 . 6 1 3}\left(\mathrm{X}_{3}\right)+\mathbf{0 . 8 2 9}\left(\mathrm{X}_{4}\right) \text {. }
$$

The equation shows that all factors have an affirmative effect on the implementation of Environmental NGOs' Projects. The regression equation also established that holding all other factors constant (no determinants or factors) implementation of Environmental NGOs' Projects) would be 0.254 meaning that there are other factors affecting implementation of e-procurement programs not considered in the model. The equation shows that all factors have a significant impact on the implementation of environmental projects in NGO's in Kwale. The regression equation shows a unit increase in stakeholders' engagement (x1) would lead to an improvement in implementation of environmental NGO's project of 0.567 while a unit increase in project design(x2) would lead to improved implementation of environmental projects by 0.412 . Project team competence (x3) when increased would lead to improvement of implementation of environmental projects by 0.613 and lastly a unit increase in monitoring and evaluation(X4) would lead to improved implementation of Environmental projects by 0.829 .

\subsection{SUMMARY OF FINDINGS, DISCUSSION, CONCLUSION AND RECOMMENDATIONS}

\subsection{Summary of Findings}

The drive of the study was to assess the impact of project management practices in the implementation of environmental NGOs' projects with an emphasis on WWF-Kenya in Kwale County. The findings were provided in accordance to the objectives discussed throughout the study as follows: The first objective was to study the effect of stakeholders' engagement on implementation of environmental NGOs projects. Reponses form respondents indicate a mean and a standard deviation of 4.4532 and 0.42114 correspondingly. The hypothesis was tested and chi square results at 0.05 level of significance showed that there is a substantial association between stakeholder engagement and implementation of environmental Non- Governmental Organizations' 
Journal of Entrepreneurship and Project Management

ISSN 2520-9116 (Online)

Vol. 6, Issue No.1, pp 24 - 48, 2021

Www.carijournals.org

projects at a $\mathrm{p}$ value of 0.00 . The multiple regression model; showed that $56.7 \%$ of the variations in successful implementation of environmental projects in NGOs was as a result of stakeholder engagement.

The second objective was to determine how project design influence on the implementation of environmental projects in Kwale County. The study findings had a mean of 4.22 std deviation of 0.446 indicating that most of the respondents agree that project design is a present element in implementation of environmental Non- Governmental Organizations' projects. The findings concluded that a good project design will have a significant positive influence on successful implementation of environmental Non- Governmental Organizations' projects this was presented by a chi square results at 0.05 level of significance showed that there is a significant relationship between stakeholder engagement and implementation of environmental Non- Governmental Organizations' projects at a $\mathrm{p}$ value of 0.01 . The multiple regression model; showed that $41.2 \%$ of the variations in successful implementation of environmental projects in NGOs was as a result of project design.

The third objective was to examine Project Team Commitment influence on the implementation of environmental projects in Kwale County. Most of the respondents, at a mean of 4.3723 and standard deviation of 0.6504 agreed that Project Team Commitment was crucial for successful implementation of implementation of environmental projects in NGOs. The findings further indicated that there is a notable connection between Project Team Commitment and implementation of environmental projects in NGOs. This clearly explained by the regression model results that show that $61.3 \%$ of the variations in implementation of environmental projects in NGOs was caused by project team competence.

The last objective was to assess how Monitoring and Evaluation Tools influences the implementation of environmental projects in Kwale County. Which produced a mean of 4.501 which indicate a strongly agree response and is affirmed by the standard deviation of 0.326 which is less than 1. The chi square test indicated a higher significant relationship with a $p$ value $=0.000$ which is less than the alpha level of significance of 0.05 . The findings further indicate that $82.9 \%$ of improvements in implementation of environmental Non- Governmental Organizations' projects were as a result of monitoring and evaluation tools.

\subsection{Discussion of Findings}

The study revealed a positive connection between all the project management practices in the study and implementation of environmental Non- Governmental Organizations' projects. The first objective was to examine the influence of stakeholder engagement in implementation of environmental projects in NGOs in Kwale. The study found out that involvement of stakeholders is crucial for success of a project. If key stakeholders are engaged from the onset of the project then this will help managers determine their needs and hence meet them. This is consistent with findings by white 2011 who cited that $65 \%$ of projects meet expectations of the stakeholders.

The second objective sought to determine how project design influence on the implementation of environmental NGO projects. The project design indicators in the study showed that it is important to review and communicate the project plan through involvement of stakeholders and allocate 
Journal of Entrepreneurship and Project Management

ISSN 2520-9116 (Online)

Vol. 6, Issue No.1, pp 24 - 48, 2021

Www.carijournals.org

resources for monitoring and evaluation as observed by Selaru, (2012). The premise was also affirmed by Meredith and Mantel (2010) who found that resource allocation improves and boosts planned start and completion dates for each project activity and involvement of stakeholder was crucial for implementation of projects. Project design is, therefore, was found to be an extensively significant to project achievement. Project design if done well will ultimately lead to accomplishment of quality project done timely and economically as planned (James, 2014).

The third objective was to examine how Project Team Commitment influences the implementation of environmental Non- Governmental Organizations' projects. The study revealed that project team competencies have significant influence implementation of environmental NGOs projects. The findings indicate that many of the respondents strongly agree with the statement that having staff who are skilled and motivated leads to project implementation success. These findings are affirmed by Thuillier (2010) who indicate that competence of the monitoring team is fundamental for realization of project objectives.

The fourth objective was to assess how Monitoring and Evaluation Tools influences implementation of environmental projects. The study establishes an affirmative affiliation among the variables. This confirmed by Phiri (2015) where he concluded that M\&E needs to be employed entirely to effect project performance. Findings indicate that Monitoring gives feedback on the regarding the project to stakeholders as concluded by Myrick (2013). The resulting information from the feedback can be used to improve performance or to overcome challenges (Ochieng \& Tubey 2013). Monitoring and evaluation are key in the sustainable project management thus the study recommends increased incidence of $M \& E$ at all the project stages (Gitonga, 2013). Monitoring and evaluation also create a level field to ensure transparency and accountability of allocated resources

\subsection{Conclusions}

In reference to the study objectives, it is evident existence of a significant correlation among Stakeholder engagement, project design, project team competence and Monitoring and evaluation tools and implementation of Environmental projects in NGOs in Kwale County. This means that project owners must ensure they identify the affected stakeholders, plan the project lifecycle well to ensure a proper management structure for proper accountability and transparency in utilization of allocated resources.

The study further concludes that project team competence can be enhanced through training and clear communication lines. Lastly, monitoring and evaluation is vital towards project implementation success. This will be easier if the project managers understand the three factors and plan for them well. Thus, this study concluded that the four independent variables are interlinked and achievement of the project objectives is reliant on how well they are all analyzed and structured.

\subsection{Recommendations}

Following the findings from the respondent in the field and the literature review, the researcher makes the following recommendation: The project management tools considered in the study will all lead to successful implementation of environmental projects and thus should be well utilized 
Journal of Entrepreneurship and Project Management

ISSN 2520-9116 (Online)

Vol. 6, Issue No.1, pp 24 - 48, 2021

$\underline{\text { www.carijournals.org }}$

and planned during the project life. Firms should ensure that stakeholders of a project are well identified and properly engaged for success in implementation of projects. Project stakeholder help in management of key issues as well as achievement of project objectives and challenges

Project design is recommended for project success because if done effectually, project design will lead to the success of projects. Project design planning helps plan allocation of resources which will be required and the level of that requirement and planned cumulative expenditure incurred by the use of resources over time this will lead to smooth implementation as challenges are managed.

Firms should ensure they have effective project leadership skills which will lead to implementation success of projects which can be achieved through training. This will enhance team competence which helps employees to perform better. Selection of a competent team is recommended as a good team is able to brainstorm to offer solutions, put long hours in the project, respect for guidelines and the right expertise is key for successful implementation of environmental projects.

The study recommended that Monitoring and evaluation system need to be structured to ascertain accountability and transparency in utilization of allocated resources and improvement of existing systems. The study recommends improvement of technical capacity and expertise in conducting Monitoring and evaluation for better performance of projects.

\subsection{Suggestions for Further Research}

The researcher suggests a study to authenticate findings using other types of projects other than environmental ones.

\section{REFERENCES}

Achieng, E. (2016). Factors influencing the performance of NGO projects in the urban informal settlements, a case of Undugu Society of Kenya.

Adan, I. H. (2012). Influence of stakeholder's role on the performance of constituencies development fund projects a case of Isiolo North Constituency, Kenya. Unpublished Masters in project planning and management, University of Nairobi

Adeyemi, I. (2013). Effects of Project Management on the Performance of a Construction Firm in Nigeria. American International Journal of Contemporary Research, 3(6), 54-58.

Affare, M. A. W. (2012). An assessment of project communication management on construction projects in Ghana (Doctoral dissertation).

Afroze, G., \& Khan, R. A. (2017, September). Investigating the impact of effective communication practices and project complexity on the performance of international development projects. In Intelligent Data Acquisition and Advanced Computing Systems: Technology and Applications (IDAACS), 2017 9th IEEE International Conference

Ahmed, R., Mohamad, N. A. B., \& Ahmad, M. S. (2016). Effect of multidimensional top management support on project success: an empirical investigation. Quality \& Quantity, 50(1), 151-176 
Journal of Entrepreneurship and Project Management

ISSN 2520-9116 (Online)

Vol. 6, Issue No.1, pp 24 - 48, 2021

www.carijournals.org

Aira, E.A. (2016). Factor's influencing the performance of non-governmental organizations projects in the urban informal settlements: A case of Undugu Society of Kenya, Nairobi County.

Arslan, G., \& Kivrak, S. (2014). Critical Factors to company success in the construction industry. International Journal of Human and Social Sciences, 4(8), 561-564

Blackstone, J. (2010). Theory of Constraints. Retrieved from http://www.scholarpedia.org/article/Theory_of_Constraints. 26th March 2013.

Bourne, L. \& Walker, D. H. T. (2016). Using a Visualizing Tool to study Stakeholder influence two Australian Examples. Project Management Journal, 37(1), 5-21

Bradley, K. (2012). Understanding PRINCE2. SPOCE Project Management Limited. Poole, Dorset.

Buba, S. P. G., \& Tanko, B. L. (2017). Project Leadership and Quality Performance of Construction Projects. International Journal of Built Environment and Sustainability, 4(2).

Chua, D., Kog, Y. \& Loh, K. (2013). Critical success factors for a different project

Danny (2014). On Stakeholder Analysis. Research On Influence of Project Management Practices on Implementation of County Governments Projects in Kenya: A Case of Nakuru County

Diallo, A. \&Thuillier, D. (2014). Critical success factors for World Bank projects: An empirical investigation. International Journal of Project Management. Vol. 30 (2) 105-116 objectives. Journal of Construction Engineering Management, 125(3), 142-150

Dissanayaka, S. M. \& Kumaraswamy, M. M. (2013). Evaluation of factors affecting time and cost performance in Hong Kong building projects. Journal of Engineering, Construct Architect Management, 6 (3), 287-298

Freeman, R. E. (1994). The politics of stakeholder theory: Some future directions. Business ethics quarterly, 409-421

Gathoni, J., \& Ngugi, K. (2016). Drivers of effective project performance in national government constituency development funded projects in Kiambu County, Kenya. International Academic Journal of Human Resource and Business Administration, 2(2), 22-40

Gilles, N. \& Yontchera, B. (2006). Does NGO aid go to the poor? Empirical evidence from Europe: IMF working paper

Gitau, L. M. (2015). The effects of Risk Management at Project Planning Phase on Performance of Construction Projects in Rwanda.

Gitonga, K. (2014). The role of project management skills on Performance of construction projects: A case study of construction firms based within Mombasa. Unpublished thesis from University of Nairobi

Goldratt, E.M. (1990). What is this thing called the theory of constraints and how should it be implemented? North river press. 
Journal of Entrepreneurship and Project Management

ISSN 2520-9116 (Online)

Vol. 6, Issue No.1, pp 24 - 48, 2021

www.carijournals.org

Gregg, A. \& Ana, L. (2016). A Framework for Exploring the Relationship Between Project Manager of Leadership Style and Project Success. The international journal of management. 1(1) pp 1-19

Hyvari, I. (2006). The success of projects in different organizational conditions. Project Management Journal, 37(4), 31-41.

Ika, A., Diallo, A. \&Thuillier, D. (2014). Critical success factors for World Bank projects: An empirical investigation. International Journal of Project Management. Vol. 30 (2) 105-116

Infragate, (2014). Project management and construction supervision

Jhuthi B, and Kimbii J (2015). Determinants of Implementation of Non-Governmental Projects in Kenya: A Case of World Vision Osiligi Ipa in Kajiado County (Master's Thesis of the University of Nairobi)

Kerzner (2013). Kerzner (2013). Project Management: A Systems Approach to Planning, Scheduling, and Controlling

Kiioh L.K. (2015). Influence of Project Management Leadership on the performance of Information Technology Projects: A Case Study of Fintech Kenya

Kimiti, F. M., \&Moronge, M. (20I8). Influence of project management practices on implementation of county government projects in Kenya: A case of Nakuru County. The Strategic Journal of Business and Change Management Vol. 5(2), 58 - 82.

Kothari, C.R. (2011). Research methodology: Methods and techniques. Revised 2nd edition. New age international publishers, New Delhi

Mackay, K. (2007). How to build Monitoring and Evaluation Toolss to support Better Government. World Bank Independent Evaluation Group, Washington, D.C, USA.

Maina, B. M. (2013). Influence of stakeholders' participation on the success of the economic stimulus programme: a case of education projects in Nakuru County, Kenya.

Mavuti, B. M., Kising'u, T. M. \& Oyoo, J. J. (2019). Effect of project management practices on implementation of Kenya Ports Authority Funded projects. The Strategic Journal of Business \& Change Management, 6 (2), 1110 - 1129

Meredith, J. R. \& Mantel, S. J. (2010). Project management. A managerial approach. Fourth edition. Wiley \& Sons.

Mkutano, S. M. \& Sang, P. (2018). Project management practices and performance of nongovernmental organizations projects in Nairobi City County, Kenya. International Academic Journal of Information Sciences and Project Management, 3(3), 1-22

Morgan, L. T. (2012). An Examination of Project Managers' Leadership Contributions to Project Success Using Critical Success Factors.

Müller, R., \& Jugdev, K. (2012). Critical success factors in projects: Pinto, Slevin, and PrescottThe elucidation of project success. International Journal of Managing Projects in Business, 5(4), 757-775 
Journal of Entrepreneurship and Project Management

ISSN 2520-9116 (Online)

Vol. 6, Issue No.1, pp 24 - 48, 2021

$\underline{\text { www.carijournals.org }}$

Munyoki J, and Mulwa A. (2012). Social Science Research: A Hand-Book, First Edition, Downtown Publishers and Printers, Nairobi, Kenya

Musila, V., \& Setlhako, A. (2014). Evaluation of Programs: Reading Carol H. Weiss. The University of South Africa, College of Education, Department of Education Leadership and Management. Pretoria, South Africa: Horizon Research Publishing

Myrick, D. (2013). A Logical framework for monitoring and evaluation: A Pragmatic Approach to M\&E. Mediterranean Journal of Social Sciences, 4(14), 423-428.

Ngatia, C. N. (2016). Institutional Determinants of Participatory Monitoring and Evaluation Systems Implementation among Community Based Development Projects in Kibera Slum, Kenya

Njogu, E. M. (2016). Influence of Stakeholders Involvement on Project Performance: A Case of Nema Automobile Emission Control Project in Nairobi County, Kenya. Unpublished MBA Project, University of Nairobi, Kenya

Novo, B., Landis, E. A., \& Haley, M. L. (2017). Leadership and its role in the success of project management. Journal of Leadership, Accountability and Ethics, 14(1), 73

Nyandika, O. F., \& Ngugi, K. (2014). Influence of Stakeholders' Participation on Performance of Road Projects at Kenya National Highways Authority. European Journal of Business Management, 1(11), $384-404$

Nyonje, R., Ndunge, K., \& Mulwa, A. (2012). Monitoring and Evaluation of Projects and Programs-A Handbook for Students and Practitioners. Nairobi: Aura Publishers.

Obegi, D. O. \& Kimutai, G. J. (2017). Resource scheduling and project performance of international not-for-profit organizations in Nairobi City County, Kenya. International Academic Journal of Information Sciences and Project Management, 2(2), 199 - 217

Obisi, C. (2011). Employer Training and Development in Nigeria Organizations: Some Observation and Agenda for Research. Australian Journal of Business and Management Research

Ochieng B. A. (2018) Determinants of an effective baseline survey for donor-funded slum upgrading projects in Nakuru County. Unpublished Master of Science in Project Management Thesis: JKUAT

Ochieng M. F., \& Tubey, D. (2013). Effectiveness of monitoring and evaluation of CDF Projects in Kenya: A case of Ainamoi Constituency. International Journal of Arts and Commerce.

Ogunde, A., Olaolu, O., Afolabi, A. O., Owolabi, J., \& Ojelabi, R. A. (2017). Challenges confronting construction project management system for sustainable construction in developing countries: Professional's perspectives (a case study of Nigeria). Journal of Building Performance, 8(1), 1-11.

Ohara, S. (2015). Project and Program Management for Enterprise Innovation, PMAJ 
Journal of Entrepreneurship and Project Management

ISSN 2520-9116 (Online)

Vol. 6, Issue No.1, pp 24 - 48, 2021

$\underline{\text { www.carijournals.org }}$

Okinyi, E. O. \& Keiyoro, P. (2019). Influence of project management practices on performance of mobile money transfer services in Nakuru County, Kenya. International Academic Journal of Information Sciences and Project Management, 3(4), 282-303

Phiri, B. (2015). Influence of monitoring and evaluation on project performance: A Case of African Virtual University, Kenya. The University of Nairobi.

Project Management Institute. (2013). A Guide to the Project Management Body of Knowledge (PMBOKGuide), 5th Edition. Pennsylvania: Institute of Project Management.

Rotich, J. (2014). Projects' Critical Success Factors: Empirical Study of Non-Governmental Organizations in Nairobi County, Kenya. International Journal of Innovative Research \&Development. Vol 3, (5) PP 288-299

Ruuska, K. (2016). Project Communication. "IPMA 96" World Congress on Project Management: Paris, France Ic8

Selaru, C. (2012). Resource Allocation in Project Management. International Journal of Economic Practices and Theories, 2(4), $274-282$

Silvius, A., Schipper, R.P., (2014). Sustainability in project management: a literature review and impact analysis. Soc. Bus. 4 (1), 63-96.

Turner, J. R., \& Muller, R. (2015). The Project Manager's Leadership Style as a Success Factor on Projects: A Literature Review. Project Management Journal, 36(2), 49 - 61.

Umulisa, A., Mbabazize, M., \& Shukla, J. (2015). Effects of Project Resource Planning Practices on Project Performance of Agaseke Project in Kigali, Rwanda. International Journal of Business and Management Review, 3(5), 29-51.

Vanesa W. and Gala D. (2011). Sound Expectations: From Impact Evaluations to Policy Change Center for the Implementation of Public Policies Promoting Equity and Growth (CIPPEC)

Wambua, M. M. (2013). Effects of Human Resource Factors on Project Performance in Nairobi County in Kenya: A Case of Selected Organizations in Westlands (Doctoral Dissertation, Kenyatta University).

Wanjiru, W. E. (2013). Determinants of Effective Monitoring and Evaluation Toolss In Nongovernmental Organizations Within Nairobi County, Kenya. Kenyatta University Masters Dissertation. Unpublished thesis.

Wanyoike, D. and Omwaka, N. (2016). Analysis of factors affecting the implementation of nongovernmental organization projects in Nakuru County, Kenya. International Journal of Economics, Commerce and Management United Kingdom. Vol. 4, (5) PP 851-870

Yang, L. R., Huang, C. F., \& Wu, K. S. (2011). The association among project manager's leadership style, teamwork and project success. International journal of project management, 29(3), 258-267. 